UNIO - EU Law Journal. Vol. 3, No. 2, July 2017, pp 34-44.

®2017 Centre of Studies in European Union Law

School of Law - University of Minho

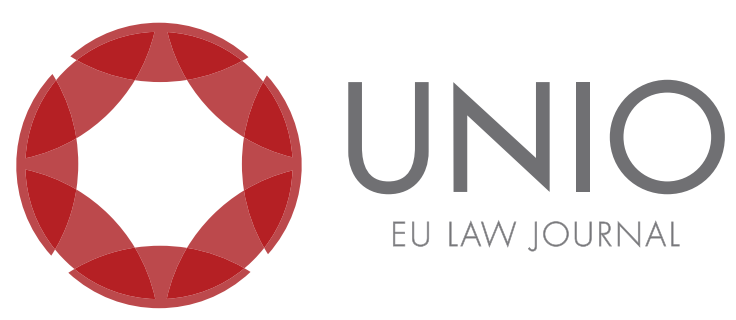

\title{
Italian regular immigration public policy: between exclusion, assimilation and integration
}

\author{
Marco Calabrò*
}

ABSTRACT: The work hereof intends to analyse some profiles of the regular migration phenomenon in Italy, by examining the most recent and relevant regulatory interventions in the welfare sector, both at state and local level. In particular, we intend to demonstrate that at least three approaches regarding the reaction of the legal system towards the access of the "other" currently co-occur in Italy. To this end, the first to be analyzed will be some examples of "exclusionary" operations will be analysed, which are based on the defense of the national cultural identity and the promotion of citizenship in its formal sense (C. Schmitt) - as they are found in several ordinances of local Authorities which restrict access to social rights for foreigners, as well as in some Regional Laws on social welfare. In addition to these exclusionary operations, even a second relational model will be examined, which is inclusive and assimilative, and therefore, opposite to the previous one, while it finds its most clear expression in the Integration Agreement, which an immigrant seeking a residency permit needs to adhere to. Finally, we will focus on a "third way", inspired by an integrative approach based on the concept of permeable identity (. Habermas), pursuant to which both they who welcome and who are welcomed are called upon to bold an attitude of mutual listening and understanding, not aimed at the incorporation of the weaker in the stronger, but rather, at the identification of common areas of dialogue that can lead to the best integration possible of two new identities (as both have made contact with the "other"). In this context, this paper aims at enhancing the role of the new public integration policies - especially at the local level - on sustainable development of current pluralist societies. In this regard, the legal instruments which are most effective in terms of developing an approach which is resilient and open-minded to communities that welcome regular immigrants, by facilitating the creation of (institutionalized and spontaneous) moments of dialogue and the sharing of knowledge of each other's cultures.

KEYWORDS: immigration - integration - resilience.

\footnotetext{
* Associate professor of administrative law at the University of Campania Luigi Vanvitelli.
} 


\section{Introduction. The "other's" entrance and the different reactions of the host society}

One of the greatest risks arising from the current phenomenon of massive migration flows in Italy is to justify the implementation of only emergent public policies, essentially inspired by the parameters of internal security ${ }^{1}$ and by the guarantee of fundamental rights, primarily those to life and health. ${ }^{2}$ The urgency to help and protect is undeniable, but it would be profoundly short-sighted - from a long-term perspective - not to recognize as much relevance the public policy, whose aim is to ensure that there is a construction of legal, social, and cultural bases for the effective integration of those people who come to Italy, not necessarily just those who to escape temporarily from unsustainable living conditions, but to also lay the foundations of a new path of life. This is the perspective from which the following reflections arise, focusing on the legal condition of the regular immigrant population, as a privileged viewpoint of the current dynamics that characterise the relationship between the host community (or, better, legal system) and the one who is received. To simplify, there seem to be, essentially, two ways in which a community reacts to the entrance of the "other" in its territory: either an attitude of exclusion, and defending social identity through the enhancement of citizenship in its traditional sense $\mathrm{e}^{3}$ or an inclusive type of attitude, aimed at allowing, on the contrary, a full assimilation of the immigrant within the community, in function of a different notion of citizenship, which we could call "dynamic". 4

The theoretical foundations of the first approach can be found in the theories

\footnotetext{
${ }^{1}$ Gabriella Lazaridis, Security, Insecurity and Migration in Europe (Ashgate Publishing, 2011); Franco Frattini, "Fenomeni migratori e sicurezza in Europa", Gnosis 4 (2015): 22; Vincenzo Cerulli Irelli, "Politica dellimmigrazione e tutela dei migranti (una discplina positiva in corso di evoluzione), Nuove Autonomie 2/3 (2013): 519.

2 Daniel Thym, "Ambiguities of Personhood, Citizenship, Migration and Fundamental Rights in EU Law", in Constructing the Person. Rights, Roles, Identities in EU Law, ed. Loïc Azoulai, Ségolène Barbou des Places and Etienne Pataut (Oxford: Hart, 2016), 111; Maria Immordino, "Pubbliche amministrazioni e tutela dei diritti fondamentali degli immigrati”, Federalismi 19 (2014): 1; Marco Borraccetti, "La prima assistenza ai migranti in arrivo tra diritti fondamentali e zone franche", Diritto, immigrazione e cittadinanza 2 (2014): 13; Franck Duvell, "Fundamental Rights of Migrants in an Irregular Situation in the European Union", in http://fra.europa.eu/fraWebsite/attachments/FRA_2011_ Migrants_in_an_irregular_situation_EN.pdf; Ryszard Cholewinski, "Human Rights of Migrants: The Dawn of a New Era?”, in http:/ / scholarship.law.georgetown.edu/imbr_2010/6; Gianluca Bascherini, Immigrazione e diritti fondamentali. L'esperienza italiana tra storia costituzionale e prospettive europee (Napoli: Iovene, 2007).

3 "Citizenship always meant the exclusion of non-members", Velt Bader, "Introduction", in Citizenship and Exclusion, ed. Velt Bader (Palgrave Macmillan, 1997), 2. For an in-depth analysis of this concept see Mario Savino, Le libertà degli altri. La regolazione amministrativa dei flussi migratory (Milano: Giuffrè, 2012), 4-12.

${ }^{4}$ The debate on the notion of citizenship has recorded several - and often completely opposed - positions. For a general overview see Margaret Coady, "Citizenship: inclusion and exclusion", in Handbook of Children and Youth Studies, ed. Johanna Wyn, Helen Cahill (Singapore: Springer, 2014), 1; Diego A. Arcarazo, "Civic Citizenship Reintroduced? The Long-Term Residence Directive as a Post-National Form of Membership”, European Law Journal 21 (2015): 200; Francesco Vetrò, “Oltre la cittadinanza: stranieri e diritti inviolabili”, in Cittadinanza inclusiva e flussi migratori, ed. Franco Astone, Francesco Manganaro, Antonio Romano Tassone, Fabio Saitta (Soveria Mannelli: Rubettino, 2009), 121; Mark Bell, "Civic Citizenship and Migrant Integration", European Public Law 13, (2007): 311; Carlo Emanuele Gallo, "La pluralità delle cittadinanze e la cittadinanza amministrativa", Diritto amministrativo (2002): 481; Giorgio Berti, "Cittadinanæa, cittadinanze e diritti fondamental?", Rivista di diritto costituzionale (1997): 16; Yasemin N. Soysal, Limits of Citizenship: Migrants and Postnational Membership in Europe (Chicago: University of Chicago Press, 1994).
} 
of Carl Schmitt, according to whom a nation is a community of individuals who share some common features such as language, place of origin, values, history and a legal system. ${ }^{5}$ Each nation/community, therefore, is deemed a profoundly cohesive reality but at the same time is closed in itself and generally "hostile" to "the other".

The second approach, however, refers to the notion of Habermas' "constitutional patriotism". ${ }^{6}$ He theorized a rationality that is common to all men, which is discursive and communicative and should bring everyone to agree upon a "common constitution". Such harmony of principles does not come to a universal dimension, as it can only be a reflection of the idea of man and a community of the hosting nation. This is the most critical element of a setting that - as open to the dialogue with the other - assumes that the latter (spontaneously) assimilates the values of the hosting nation. Experience shows that it is not uncommon for some of those principles that, according to Habermas, should be felt as common "by nature", may conflict with some identity "dogmas" of the immigrants: by way of example, I can refer to the female genital mutilation (infibulation), that violates several fundamental rights recognized by any western legal system. This makes it substantially impossible to imagine a mutual understanding between the two opposing viewpoints the recognition of minority rights finds a specific limit. ${ }^{7}$

\section{The exclusionary pushes and the "shy" responses of the Italian Constitutional Court}

Upon examination of some of the main Italian legal phenomena regarding the relationship between indigenous and immigrant communities - albeit antithetical - it appears that both the aforementioned approaches currently, (paradoxically) coexist in the Italian legal system.

A clear manifestation of the exclusionary attitude has emerged in the necessity and urgency ordinances, by means of which many mayors have made the access criteria more selective to the registry office for the regularly resident migrant population in Italy. Since 2008, due to the increasing tendency of the migration flow and the increasing assignment of powers to local administrators pursuant to the so-called Security Package, the so-defined "season of ordinances" has begun: necessity and urgency resolutions aimed at - pursuant to public security reasons - making the access criteria more selective to the registry office, by introducing more stringent requirements than those provided by state law. ${ }^{8}$ The Constitutional Court intervened by means of a Resolution, stating the illegitimacy of the state provision which allowed mayors to give effect, through ordinances, to permanent long-term effects capable of affecting fundamental rights and freedoms. ${ }^{9}$ But, the exclusionary attitude, at the

\footnotetext{
${ }^{5}$ Carl Schmitt, Le categorie del politico (Bologna: Il Mulino, 1998).

' Jürgen Habermas, La costellazione postnazionale - Mercato globale, naz̧ioni e democrazia (Milano: Feltrinelli, 2002), 50.

7 On this subject see Susan M. Okin, Is Multiculturalism Bad for Woman (Princeton: Princeton University Press, 1999). For a theory of minority rights respectful of fundamental rights and freedom see Will Kymlicka, Multicultural Citizenship (Oxford: Oxfrod University Press, 1995).

8 Angela Musumeci, "Sicurezza, migranti e livelli di governo", in Immigrazione e integrazione, dalla prospettiva globale alle realtà locali, I, ed. Francesco Rimoli (Napoli: Editoriale Scientifica, 2014), 461. Nazzarena Zorzella, "I nuovi poteri dei sindaci nel pacchetto sicurezza e la loro ricaduta sugli stranieri", Diritto, immigrazione e cittadinanza 3/4 (2008): 57.

${ }^{9}$ Const. Court, 7 April 2011, n. 115. See also Pasquale Cerbo, "Principio di legalità e «nuove ed inedite» fattispecie di illecito create dai Sindac?”, Le Regioni 1/2 (2012): 215.
} 
local level, cannot be considered fully exceeded yet. Given I am referring to the discretionary power given to the local administrations in deciding to enhance worsen the inspections on the sanitary conditions of the houses declared habitual residence by the immigrant: any negative outcome of the inspection may lead to the ban on registration at the registry office. ${ }^{10}$

Even more significant is the experience of the most recent regional laws on access to social services for foreigners who are regularly resident in Italy. ${ }^{11}$ In this regard, there is the issue of those welfare benefits which go beyond the fundamental rights, but are still recognized to all citizens demonstrating an ability to meet certain requirements. It's clear that the pretty high degree of recognition of the right to receive such services also in the case of (regular) immigrants is a primary indicator of the relationship model existing between a legal system and the immigrants. ${ }^{12}$

Issues primarily concern legislative power. According to Article 117 of the Italian Constitution, immigration falls within the area of the exclusive State powers, while it seems to exclude any jurisdiction at the regional level. However, the Italian Constitutional Court has immediately clarified that only the area of the entrance and the residency permit of foreigners in Italy regard the State's legislative power in its strict sense (public security), ${ }^{13}$ whereas, on the contrary, other areas (assistance, education, health, etc.) must be managed in close coordination between the State and the Regions. ${ }^{14}$ As opposed to what concerns health, social assistance is assigned to the exclusive regional competence. This might lead to the conclusion that all the profiles unrelated to security or health, but to social welfare, should be solely governed by Regional laws.

However, together with regional regulations aimed at extending access to welfare benefits to foreigners who regularly reside in Italy, irrespective of the length of their stay, ${ }^{15}$ in recent years, several regional laws have been published which - on

${ }^{10}$ For a general overview of recent contradictory Italian local residence policies see Enrico Gargiulo, "Le politiche di residenza in Italia: inclusione ed esclusione nelle nuove cittadinanze locali", in $L a$ governance dell'immigrazione. Diritti, politiche e competenze, ed. Emanuele Rossi, Francesco Biondi Dal Monte, Massimiliano Vrenna (Bologna: Il Mulino, 2013), 135.

${ }^{11}$ On the so called residential citizenship, that is the connection between residence and enjoyment of several social rights, regardless of the formal nationality, see Rainer Bauböck, Transnational Citizenship: Membership and Rights in International Migration (Cheltenham: Edward Elgar, 1994); Seyla Benhabib, The Rights of Others. Aliens, Residents and Citizens (Cambridge: Cambridge University Press, 2004), 10; Andrea De Bonis and Marco Ferrero, "Dalla cittadinanza etno-nazionale alla cittadinanza di residenza”, Diritto, immigrazione e cittadinanza 2 (2004), 49.

${ }^{12}$ See Cecilia Corsi, "Servizi sociali agli immigrati", in Cittadinanza inclusiva e flussi migratori, ed. Franco Astone, Francesco Manganaro, Antonio Romano Tassone, Fabio Saitta (Soveria Mannelli: Rubettino, 2009), 95. In the European context, is particularly significant the Long Term Residence Directive (2003/109/CE). As far as it concerns in this context, through the study of several cases dealing with this directive, has been underlined that «rights are not considered as a prize for an already successful and completed integration», Arcarazo, "Civic Citizenship Reintroduced?”, 321.

${ }^{13}$ Const. Court, 18 January 2013, n. 2; Const. Court, 15 April 2010, n. 134; Cons. Court, 14 May 2008, n. 131.

${ }^{14}$ Const. Court, 25 February 2011, n. 61; Const. Court, 7 March 2008, n. 50; Const. Court, 14 April 2006, n. 156. For an interesting analysis of this issue see Gianluca Bascherini, "Il riparto di competenze tra Stato e Regioni in materia di immigrazione al tempo del «pacchetto sicurezza》. Osservazioni a margine delle sentt. nn. 269 e 299 del 2010”, Giurisprudenza Costituzionale 5 (2010): 3901.

${ }^{15}$ For instance, 1.r. Emilia Romagna, 24 marzo 2014, n. 5; l.r. Abruzzo, 13 dicembre 2014, n. 46; 1.r. Campania, 8 febbraio 2010, n. 6; l.r. Toscana, 9 giugno 2009, n. 29 (whereon see Paolo Passaglia, "La legge regionale toscana sull'immigrazione: verso la costruzione di una società plurale. Commento alla legge regionale n. 29/2009", in La governance dell'immigrazione. Diritti, politiche e competenze, ed. 
the basis of economic reasons - have ruled in very restrictive terms. ${ }^{16}$

Also in this context, the Italian Constitutional Court has intervened on several occasions, stigmatising the use of citizenship and long-term residence requirements as exclusion criteria. ${ }^{17}$ However, the protection afforded by the Court appears to be weak, since in its judgments, it does not call into question the legitimacy of restrictive regional measures, but merely challenges its content under the sole profile of reasonableness. In particular, according to the Court - despite the status of regular tax payer of the regular immigrant, the regional provisions which discriminate against access to welfare benefits would be legitimate if they were based on "not blatantly irrational' reasons. ${ }^{18}$

Such a submissive attitude of the Court could, over time, prove to be fragile and lead to unreasonable disparities in the national territory in access to assistance services for the foreigner. To avoid such a scenario, the reference to the exclusive legislative power of the State on the determination of the basic level of benefits relating to civil and social entitlements could help. Given the improbable justifiability of restrictive legislation to regular immigrants - on the constitutional level - in the light of their status as tax payers, even supporting the position of those who assume their unconditional access to all social care services is intolerable, the legitimacy of the related limitations should be verified not only on the criterion of reasonableness in Article 3 of the Italian Constitution, but also on Article 117(2)(m). The exercise of the exclusive legislative power of the State in the field of basic level of benefits would thus, be able to ensure an adequate uniformity of treatment throughout the national territory, while respecting the regional and local autonomy now recognized by the law, through the faculty to waive in melius the general national standards. ${ }^{19}$

\section{The assimilative logic and the consequent risk of confusion between law and morality}

Coming to the second relational model that may be established between a legal system and the regular immigrant, i.e., the assimilative type, the Integration Agreement is an undoubtedly appropriate example. It represents a kind of contract between the Italian State and the foreigner, through which the regular immigrant undertakes to acquire certain credits within a certain time, on pain of revocation of the residency permit. ${ }^{20}$ The acquisition of the aforementioned credits takes

Emanuele Rossi, Francesco Biondi Dal Monte, Massimiliano Vrenna (Bologna: Il Mulino, 2013), 437).

${ }^{16}$ For instance, 1.r. Lombardia, 12 febbraio 2002, n. 1; 1.r. Friuli Venezia Giulia, 31 marzo 2006, n. 6; l.p. Trento, 24 luglio 2012, n. 15.

${ }_{17}^{17}$ See Const. Court, 4 July 2013, n. 172; Const. Court, 9 February 2011, n. 40; Const. Court, 2 December 2005, n. 432. See also Guido Corso, Straniero, cittadino, nomo. Immigrazione ed immigrati nella giurisprudenza costituzionale, Nuove autonomie (2012): 390.

${ }^{18}$ Const. Court, 4 July 2013, n. 172; Const. Court, 2 December 2005, n. 432. For a comment see Marco Calabrò, Livelli essenziali delle prestazioni sociali e politiche pubbliche per l'integrazione, www. giustamm.it (2015): 1; Matteo Gnes, Il diritto degli stranieri extracomunitari alla non irragionevole discriminazione in materia di agevolazioni sociali, Giurisprudenza costituzionale (2005): 4681.

${ }^{19}$ Cecilia Corsi, "Immigrazione e diritti sociali: il nodo irrisolto del riparto di competenze tra Stato e regioni", in La governance dell'immigrazione. Diritti, politiche e competenze, ed. Emanuele Rossi, Francesco Biondi Dal Monte, Massimiliano Vrenna (Bologna: Il Mulino, 2013), 244-251.

20 bttp://wnw.libertaciviliimmigrazione.dlci.interno.gov.it/it/accordo-dintegrazione. For a thorough analysis of this document see Francesca Biondi Dal Monte and Massimiliano Vrenna, "L'accordo di 
place through the attendance of training courses, covering topics such as the Italian language, the Constitution, the educational system, and healthcare, etc., as well as expressed adhesion to the Charter of Values of Citizenship and Integration. ${ }^{21}$ The latter, in particular, is a document summarizing and explaining the fundamental principles and values of Italian law which regulate the collective life of citizens and non-citizens, which the regular immigrant is essentially obliged to join.

In this context, it is important to emphasize that the foreigner is required not simply to know and respect (which would evidently be shareable) the national culture and values, but rather to embrace them. This is the expression of an assimilative rather than integrative logic, intended to "void" diversity rather than to limit it. ${ }^{22}$

To this end, are of great interest the studies carried out on the assimilation policies adopted in Japan towards the end of the 1800s with regard to the Ainu minority, which included, inter alia, the encouragement of mixed marriages and the obligation to cultivate land, with the related prohibition of living according to the traditional nomadism models this has led to the almost complete extinction of the Ainu population over the years. ${ }^{23}$

However, the theoretical reference of the Integration Agreement and the related adhesion to the Charter of Values could, prima facie, be found in Habermas' quoted thesis on constitutional patriotism. But, actually, the immigrant does not decide to embrace the values of the said Charter as recognition of the universal goal of "common constitution"; he/she is instead forced to sign a contract of adhesion not merely concerning synallagmatic performances, but rather its own value system - without having the opportunity of negotiate on its content.

Some excerpts of the Charter of Values are particularly significant where, for example, it is stated that the immigrant is required to "... share the principles regulating the Italian society..." or that "...living in the same territory means to be full-fledged citizens of that land and acquire, with loyalty and coherence, common values and share responsibilities...", until even demanding that "...no one can say to be offended by the signs and symbols of a religion different from his/her own...". It clearly outlines a serious confusion between law and morality, between rules to be respected and improper invasion of the intimate feeling of each individual. ${ }^{24}$

The rationale underlying this approach lies in a twofold order of consideration. Firstly - recalling the thesis of Mill's "cultural monism" - the failure to recognize the identities and cultures of different ethnic groups is justified on stability and security requirements, which are presumed to be more guaranteed by unity rather than by pluralism..$^{25}$ In other words, it is looming a peculiar application of the theory of

integrazione ovvero l'integrazione per legge. I riflessi sulle politiche regionali e locali', in $L a$ governance dell'immigrazione. Diritti, politiche e competenze, ed. Emanuele Rossi, Francesco Biondi Dal Monte, Massimiliano Vrenna (Bologna: Il Mulino, 2013), 253.

${ }^{21}$ http:/ / mmm.libertaciviliimmigrazione. dlci.interno.govit/it/documentazione/ circolari/carta-dei-valori-della-cittadinanza-edellintegrazione.

${ }^{22}$ Enrico Gargiulo, Integrazione o esclusione? I meccanismi di selezione dei non cittadini tra livello statale e livello locale, Diritto, immigrazione e cittadinanza (2014): 41.

${ }^{23}$ Noémi Godefroy, "The Ainu assimilation policies during the Meiji period and the acculturation of Hokkaidô's indigenous people", http://mmm.popjap.fr/blog/wp-content/uploads/2012/01/Godefroy_Ainu_assimilation_policies. $p d f$.

${ }^{24}$ Steven Shavell, "Law versus Morality as Regulators of Conduct", American Law Economic Review 4 (2002): 227

${ }^{25}$ Katherine Smits, "John Stuart Mill And The Social Construction Of Identity", History of Political Thought 25 (2004): 298. 
utilitarianism theorized by Bentham, according to which the choices of the governors should not be dictated by moral reasons but aimed at achieving the maximum benefit for the majority of the associates. ${ }^{26} \mathrm{It}$, thus, raises the real nature of the Integration Agreement which - although sold as an integration tool - is rather a selection tool, aimed at reducing the (potentially) adverse effects on Italian citizens, allowing the permanence in the national territory only for immigrants willing to renounce (at least 'in public') their identity to embrace in full a new culture and new values. ${ }^{27}$

From another point of view, restrictive positions in terms of recognition of identity rights to the immigrant population are based on the idea of the 'inessentiality' of the differences. Since the Declaration of the Rights of Man and of the Citizen of $1789,{ }^{28}$ the model of the modern democratic State is based on the conviction that what unites us is more relevant than what divides us. It had, among other things, the consequence of weakening the attention to the protection of the differences (in race, gender, religion, etc.) in the name of a 'forced' interpretation of the principle of formal equality..$^{29} \mathrm{It}$ is not a coincidence if one of the greatest exponents of modern liberal thought, John Stuart Mill, considered the request of safeguarding cultural identities by minorities as an obstacle to the development of a fair and solid society. He rather indicated the path of the absorption of ethnic groups within the national culture, defined as beneficial if in favor of a more advanced nationality. ${ }^{30}$

\section{The multicultural approach and the recognition of identity rights}

From what has previously been stated, it is clear how, both, the exclusionary and the assimilative approach show many critical issues. In fact, on the one hand, they do not seem to be able to guarantee the implementation of a safe and peaceful social model and, on the other hand, although they are based on antithetical grounds, they both end up not recognizing the immigrant's identity rights: one, due to the defense of national cultural identity, the other, because of supposed needs for democratic equality and public safety.

Such "unitary" social models contrast the idea based on multiculturalism, namely on recognition and, where necessary, protection of cultural diversity. ${ }^{31}$ The underlying

\footnotetext{
${ }^{26}$ Jeremy Bentham, Introduzione ai principi della morale e della legislazione (Torino: Utet, 1998).

${ }^{27}$ For an overview of EU policies on integration clauses concerning regular migration see Stefano Montaldo, "Integration examinations for regular migrants: the difficult search for a balance between national competencies and full effectiveness of EU law”, EU Law Journal 2 (2016): 39.

${ }^{28}$ See Keith Baker, "The Idea of a Declaration of Rights", in The French Idea of Freedom: The Old Regime and the Declaration of Rights of 1789, ed. Dale Van Kley, (Stanford: Stanford University Press, 1997), 154; Immanuel Wallerstein, "Citizens All? Citizens Some! The Making of the Citizen", Comparative Studies in Society and History 45, (2003): 650.

${ }^{29}$ For a critique of this position see Axel Honneth, La lotta per il riconoscimento, (Milano: Il Saggiatore, 2002).

${ }^{30}$ «Experience proves that it is possible for one nationality to merge and be absorbed in another: and when it was originally an inferior and more backward portion of the human race the absorption is greatly to its advantage», John S. Mill, Representative government (Kitchener: Batoche, 2001), 185.

${ }^{31}$ For a general overview on multiculturalism model of society see Charles Taylor, Multiculturalism and «The Politics of Recognition» (Princeton: Princeton University Press, 1992); Bhikhu Parekh, Retbinking Multiculturalism. Cultural Diversity and Political Theory (London: Palgrave, 2005); Gaetano Azzariti, "Multiculturalismo e Costituqione", Politica del diritto 1-2 (2016): 3; Carlo Di Marco, "Il multiculturalismo alla prova della democrazia occidentale. I diritti degli stranieri nei territori di accoglienza", Democrazia e diritto 1-2 (2012): 383.
} 
danger to this approach is obviously to legitimise attitudes of identity closure. Refusing to adapt to the new social and political reality in which we are involved it would lead to the formation of a fragmented community of non-dialogic ethnic monads, i.e. the plural monoculturalism. ${ }^{32}$ Nevertheless, it has been effectively noted in this regard that "...national minorities do not want isolation but an integration that is respectful of the distinctive character of theirgroup...", 33 in a perspective, therefore, of mutual recognition of enriching but non-exclusionary diversities. Our society is intended to be increasingly pluralistic, whether it is desired or not: the challenge is not to cancel or even exalt individual identities, but to avoid creating fragile convictions founded on opposing ethnic groups and stemming stances that are unavailable to dialogue, enhancing the essential contents of a common feeling. ${ }^{34}$

Firstly, this presupposes a reconsideration of the idea of identity, i.e. more flexible and dynamic or, better, 'permeable'. In the wake of Habermas' argumentative democracy theory, both the host and the one who is received must act in an attitude of mutual listening and understanding, not aimed at the incorporation of the weaker in the stronger (or more numerous), ${ }^{35}$ but rather, at the identification of common areas of dialogue that can lead to the best integration possible of two new identities (since both have come in touch with the "other"). ${ }^{36}$

In order for this to happen, it is obviously necessary that the debate and the research of the sharing elements both take place on a totally laical basis, not characterized by untouchable fields of truth (i.e. religious or ethical). The latter - whose existence cannot be denied since they are part of the system of values of any community - must, however, necessarily remain out of the public integration policies, and must be managed at a different and higher relational level, based on the recognition of fundamental rights and the principle of tolerance. So, it is essential that this approach - hard but not utopian - be the bedrock of public policies, especially local ones, as it is perhaps the only one able to guarantee a peaceful development of the new pluralistic societies.

In Italy, this approach finds hesitant attempts of concretisation in some regional regulations on immigrants' integration, as concrete measures of cultural and social inclusion are provided for. With the launch of Italian language courses for migrant students and workers and the organization of intercultural education's projects in schools and universities, aimed at preserving the cultural values and identities of immigrant populations; the provision of cultural mediation in hospitals, schools and public offices in Italy is getting better. ${ }^{37}$

\footnotetext{
${ }^{32}$ See Amartya K. Sen, Identità e violenza (Roma-Bari: Laterza, 2008).

${ }^{33}$ Patrick Savidan, Il multiculturalismo (Bologna: Il Mulino, 2010), 71.

${ }^{34}$ In this sense, we should refer to the "reflective equilibrium" theorized by John Rawls, $A$ Theory of Justice, (Cambridge, MA: Harvard University Press, 1971), 65, according to which if judgments of two or more people conflict in some way, it is possible to proceed by adjusting their various beliefs until they are in "equilibrium" stable.

${ }^{35}$ «La strada dell'eguaglianza è una strada dialogica, in cui le identità individuali e collettive si formano e si trasformano continuamente attraverso il riconoscimento dell'altro che da immigrato (o comunque non cittadino) diventa persona eguale alle altre persone, con gli stessi diritti e gli stessi doveri» Paolo Carrozza, "Noi e gli altri. Per una cittadinanza fondata sulla residenza e sull'adesione ai doveri costituzionali", in La governance dell'immigrazione. Diritti, politiche e competenze, ed. Emanuele Rossi, Francesco Biondi Dal Monte, Massimiliano Vrenna (Bologna: Il Mulino, 2013), 59.

36 Jürgen Habermas, L'inclusione dell'altro (Milano: Feltrinelli, 2013), 151. See also Pier Luigi Zanchetta, "Lo Stato-Nazione tra multiculturalismo e globalizzazione. Analisi e proposte di Jurgen Habermas" Diritto, Immigrazione e Cittadinanza 1 (2000): 14.

${ }^{37}$ See, for instance, l.r. Campania, 8 February 2010, n. 6; 1.r. Toscana, 9 June 2009, n. 29; 1.r. Marche,
} 


\section{Public integration policies and resilient societies}

In this context, the dynamics of resilient communities' behaviors comes to the aid as a constituent element of effective integration policies. In relation to the phenomenon of immigration, it is possible to identify at least two areas of resilience. By observing the community that hosts the immigrant, it arises as it tends to assume an attitude aimed to face the difficulties threatening its physical and social environment. This can lead - although not entirely consciously - to an exaltation of the sense of community and to an attitude of hostility towards the cause of breakup of the former state of (ostensible) equilibrium. ${ }^{38}$ Conversely, several studies show that a resilient community is also a dynamic community, ready to change and find a new balance in relation to pressures coming from outside. ${ }^{39} \mathrm{It}$ is, precisely, the development of such an attitude that should be fostered by public integration policies.

In a different light, it should be noted that the justifiable resilient attitude of immigrant communities (who share difficulties in entering and staying in a new country), as it is likely to degenerate, if not adequately channeled, into self-marginalisation, closing dialogue, and radicalisation of diversity. ${ }^{40}$ Keeping their traditions alive, creating moments of community sharing and fighting for the right to profess their faith, are all phenomena perfectly consistent with the attitude of a "constructive resistance", by which man avoids succumbing to the enormous difficulties deriving from immigration (often not voluntary, but imposed by need). Only if such phenomena are fostered by public policies aimed at a genuine integration within the new community, it is possible to imagine the development of a sustainable pluralist society.

In this sense, inter alia, a differentiated analysis of the resilience behaviors of each immigrant communities would be desirable. The foreigner stress factors are, essentially, universal: language difficulties, a sense of marginalization, and self-determination incapability; cultural misunderstanding are all common examples. However, the reactions to these stressors are not always the same. Several studies demonstrate significant differences between ethnic groups concerning risk exposure and dealing with difficulties. ${ }^{41}$ Therefore, public integration policies - and not merely assimilation policies - should also take into account this factor and should be structured flexibly and be adaptable to the resilience of different models that characterize the main ethnic groups.

\section{Concluding remarks}

In conclusion, the said integrative approach seems to find its basis in the

26 May 2009, n. 13; l.r. Liguria, 20 February 2007, n. 7; 1.r. Puglia, 4 December 2009, n. 32; 1.r. Lazio, 14 July 2008, n. 10; 1.r. Abruzzo, 13 December 2004, n. 46.

${ }^{38}$ Caroline S. Clauss-Ehlers and Liliana Lopez Levi, "Violence and Community, Terms in Conflict: An Ecological Approach to Resilience", Journal of Social Distress and the Homeless 11 (2002): 265.

${ }^{39}$ Charles S. Carver, "Resilience and thriving: issues models and linkages", Journal of Social Issues 2 (1998): 245.

${ }^{40}$ Nyla R. Branscombe and Naomi Ellemers, "Coping with group-based discrimination: Individualistic versus group-levelStrategies", in Prejudice: The target's perspective, ed. Jaten K. Swim, Charles Stangor (San Diego: Academic Press, 1998); Monica Pellerone and Alessia Maria Gervasi, "Il percorso d'integrazione", in Percorsi migratori e cambiamenti identitari nella sfida all'integrazione, ed. Monica Pellerone and Valeria Schimmenti (Milano: Franco Angeli, 2014), 97.

41 Anna Zlobina et al. "Sociocultural adjustment of immigrants: Universal and group-specific predictors", International Journal of Intercultural Relations 2 (2006): 195 
categories of bio-politics - as listed by Foucault - where it identifies the main object of politics in the protection of human life as a value in itself. ${ }^{42}$ Of course, there is a strong risk that life-enhancing goals in the bio-political framework may be reflected in the protection of health and identity of their own citizens by their own governments, with the inevitable consequence of closure towards the exterior and of legitimising foreclosure in the name of public safety. By contrast, the bio-politics - as ars governandi - must be considered as a model of political confrontation and cultural development, aimed at ensuring the good of the community by means of constant democratic effort to reconcile the need for universality with the ethical and cultural pluralism of current multiethnic societies. The challenge of multiculturalism, after all, is precisely to recognize the value of "diversity", while ensuring social cohesion. ${ }^{43}$

In a different perspective, the study of the migratory phenomenon also refers to bio-politics theory as theorized by Hardt and Negri, understood as the natural tendency of postmodern society to meet its own needs, resisting the legal and economic institutions that aim to control and regulate it in all its (economic and social) activities. ${ }^{44}$ An effective public policy of integration, should also adopt instruments to overcome the stress factor consisting in the incapability of the immigrant to actively participate in the social life of the new community in which he/she lives. ${ }^{45}$

In this regard, the experience of some local areas should be noted, as it is provided that the public authorities prefer to use the immigrants for cultural mediation activities, ${ }^{46}$ obviously only if suitably qualified. Or, moreover, the so-called Board for Integration (whose functions are, essentially, advisory and propositional), present in many regions, which include, as members (and not only as recipients), representatives of the immigrant communities. ${ }^{47}$

In conclusion, the proposed public policy model, inspired by the concrete respect for cultural diversity and by the promotion of mutual and participatory integration, seems not to be a mere option for the national and regional legislators, but rather, a constitutional duty. Such is, first of all, due to a non-improperly egalitarian interpretation of Art. 3 of the Italian Constitution: the only inequalities to be tackled are the discriminatory ones; by imposing a forced and transversal equality, this ends up being discriminatory in itself and contrary to the principle of substantial equity. ${ }^{48}$

\footnotetext{
${ }^{42}$ Michel Foucault, Nascita della biopolitica, (Milano: Feltrinelli, 2004). See also Jacopo Martire, “The Rule of Law: A Foucauldian Interpretation, In-Spire Journal of Law, Politics and Societies 6 (2011): 19.

${ }^{43}$ «Democracies are in a standing dilemma. They need strong cohesion around a political identity, and precisely this provides a strong temptation to exclude those who can't or won't fit easily into the identity which the majority feels comfortable with, or believes alone can hold them together. And yet exclusion, besides being profoundly morally objectionable, also goes against the legitimacy idea of popular sovereignty, which is to realize the government of all the people» Charles Taylor, Dilemmas and Connection (Cambridge: Harvard University Press, 2011), 138.

${ }^{44}$ Michael Hardt and Antonio Negri, Impero. Il nuovo ordine della globalizzazione (Milano: Rizzoli, 2002).

${ }^{45}$ Elisa Olivito, "Primi spunti di riflessione su multiculturalismo e identità culturali nella prospettiva della vulnerabilita” Politica del diritto 1 (2007): 98-101.

${ }^{46}$ See, for instance, 1.r. Abruzzo, 13 December 2004, n. 46. For a thorough analysis of this fundamental moment of the integration policy see Chiara Bergonzini, La mediazione culturale: uno strumento (sottovalutato?) per l'integrazione degli immigrati, Diritto, immigrazione e cittadinanza (2009): 67.

${ }^{47}$ See l.r. Campania, 8 February 2010, n. 6; 1.r. Marche, 26 May 2009, n. 13; 1.r. Puglia, 4 December 2009 , n. 32; 1.r. Lazio, 14 July 2008, n. 10. For a critical comment on the Board of integration model of intervention see Marta Ferrara, "I diritti di partecipazione dell'immigrato: il Consiglio provinciale dell'immigrazione", in I diritti degli altri. Gli stranieri e le autorità di governo, ed. Enzo Di Salvatore, Michela Michetti (Napoli: Editoriale Scientifica, 2014), 269.

${ }^{48}$ The foundation of multiculturalism is to consider true equality just that which doesn't hide
} 
The constitutional constraint also derives from paragraph 4 of Art. 118 of the Italian Constitution. The enhancement of the principle of horizontal subsidiarity, also regarding the management of the migratory phenomenon, ${ }^{49}$ would, in fact, have a twofold advantage: firstly, it would help the (regular) immigrant to feel 'part' of the community, rather than an extraneous burden, thus achieving also the constitutional purpose of the full development of each person. An active social attitude by regular immigrants would then facilitate the local authorities themselves in developing more mindful and, therefore, more effective integration policies.

(non-discriminatory) differences, but allows a peaceful coexistence. From a different point of view, a blind egalitarianism would also collides with the s.c. positive discrimination, which allows distinguished policies aimed at making sure that people such as women, members of smaller racial groups, and people with disabilities get a fair share of the opportunities available, see Michael Sandel, Giustizia. Il nostro bene commune (Milano: Feltrinelli, 2009), 188. See also Council Directive 2000/43/EC of 29 June 2000, on "Implementing the principle of equal treatment between persons irrespective of racial or ethnic origin", art. 5 "With a view to ensuring full equality in practice, the principle of equal treatment shall not prevent any Member State from maintaining or adopting specific measures to prevent or compensate for disadvantages linked to racial or ethnic origin".

49 Gregorio Arena, "Immigrazione e cittadinanze", in Poteri pubblici e laicità delle istituzioni, ed. Riccardo Acciai, Fabio Giglioni (Roma: Aracne, 2008), 113. 